\title{
The Interdependence between Young Students' Reading Attitudes, Reading Skills, and Self-Esteem
}

\author{
Tuula Merisuo-Storm \\ Marjaana Soininen
}

\author{
University of Turku, Finland, Department of Teacher Education, Rauma Unit
} tuumer@utu.fi,marjasoi@utu.fi

\section{Doi:10.5901/jesr.2014.v4n2p122}

\begin{abstract}
Learning to read is young students' main goal during the first school years. Reading skills are an important tool that they need to become academically successful. A child who does not learn to read and comprehend different texts in the early school years has severe difficulties also in studying other school subjects. The study described in this article aimed to find out what kind of self-esteem, reading skills and attitudes towards reading and studying children have during their first two school years. To measure children's self-esteem we used a questionnaire of 50 items (see Article Soininen \& Merisuo-Storm). Students' reading skills were assessed in the second grade with a reading comprehension test. They read a nonfiction text of a squirrel and answered questions related to the text. Answers to the easiest questions could be found in the text but when answering the most difficult question the students had to make connections that are not clearly expressed in the text. It means that they had to be able to "read between the lines". To find out what kind of reading attitudes the first and the second graders have towards reading we constructed a questionnaire including 17 questions for all pupils and five extra questions for the second graders. The questionnaire covers four different areas: 1) attitudes towards reading, 2) attitudes towards studying, 3) attitudes towards social reading, and 4) feeling of competence. The scale used in the questionnaire is a Likert-type 1-4 (agreedisagree). 563 children (281 boys and 259 girls) took part in the study. The results show that children's self-esteem correlates significantly with their reading comprehension skills $(r=.310, p=.000)$, reading attitudes $(r=.419, p=.000)$, and attitudes towards studying $(r=.384, p=.000)$. The students who have good self-esteem have good reading skills and positive attitudes towards reading and studying. When looking at the different parts of the self-esteem questionnaire, the strongest correlations are between students' selfhood and attitude towards studying $(r=.376, p=.000)$ as well as between affiliation and attitude towards studying $(r=.348, p=.000)$. This indicates that children, who are confident and happy being what they are as well as get well along with their peers, enjoy studying. Even more often than those children who are conscientious or have a high feeling of competence. The results show that students' self-esteem has a strong effect on their learning and attitudes. However, when we know how important it is for the first and second graders to acquire good reading skills, it is also possible that learning to read has a positive effect on young students' self-esteem. Therefore, it is essential that the teachers support the positive development of each student's self-esteem as well as reading skills and attitudes.
\end{abstract}

Keywords: reading attitudes, reading comprehension, self-esteem, first and second grade

\section{Introduction}

The European Union unveiled in September 2012 the final report of EU high-level group of experts on literacy (http://ec.europa.eu/education/literacy/what-eu/high-level-group/documents/literacy-report.pdf). According to the report, in Europe one in five 15 year olds and nearly 75 adults lack basic reading and writing skills. Consequently, they have difficulties in getting employed and therefore have a great risk of poverty and social exclusion. In addition, as Mullis, Martin, Kennedy, Trong, and Sainsbury (2009) point out, ability to read is fundamental to each person's intellectual development. Good literacy skills are in today's digitized world more essential than ever before. They improve people's lives and promote knowledge, innovation and growth. Countries, which have a large number of students who lack basic reading skills at the age of 15 , are likely to be held back in the future. Investments aiming to improve all citizens' literacy skills are beneficial also from the economic point of view. They produce concrete gains as well for individuals as for society. (OECD, 2013; The final report of EU high-level group of experts on literacy, 2012.)

In Finland it is taken for granted that all citizens are literate. Also international assessments (PISA; PIRLS) have shown that Finnish students have excellent reading skills. PISA assessed the reading skills of 15 year old and PIRLS 1011 year old students. The PISA2012 report explains what is behind Finnish students' good reading skills. Early detection 
mechanisms, such as students' individualised assessments by class and special education teachers, make it possible to identify struggling learners. Consequently, the students get necessary support early on and are able to continue their education at the same pace as their peers. However, it is important to pay attention to the fact Finnish students' performance in the last PISA (in 2012) and PIRLS (in 2011) was - although still very good - not as good as it had been in the previous assessments. (Kupari, Sulkunen, Vettenranta, \& Nissinen, 2012; Mullis et al., 2009; OECD, 2013.)

There is a significant gender gap in the results of the reading assessments mentioned above. Girls outperform boys in reading almost everywhere. This gender gap is especially large in some high-performing countries, where almost all the low achievers in reading are boys. A disquieting result is that between PISA 2000 and PISA 2012 the gender gap in reading performance widened in 11 countries. Low-performing boys are heavily over-represented among the group of the students who fail to show basic levels of reading literacy. PISA results indicate that to be able to fulfil one's potential one needs determination, motivation, and confidence in oneself. Low achievers have a low level of engagement in reading. Students can only achieve at the highest levels when they are motivated to work and believe that they are in control of their success and capable of achieving at high levels. To close the gender gap in reading performance, new ideas aiming to attract interest and engagement among boys in literary culture and helping them to find pleasure in reading are badly needed. (OECD, 2013; Välijärvi et al., 2007.)

The goal of the present article is to examine what kind of reading skills and reading attitudes the first and the second graders have and if there is interdependence between students' skills, attitudes and self-esteem. In addition, it aims to find out if there is a difference in the girls' and the boys' results.

\section{Learning to Read}

Skilled reading can be defined as the ability to read accurately and fluently and to comprehend what is read. Although children acquire reading literacy through activities and experiences in various environments, young students' reading skills and attitudes towards reading literacy develop mainly at home and in school. (Suggate, Schaughency \& Reese, 2013.) According to Luke and Freebody (1999), effective literacy utilizes a variety of practices. Their Four Resources Model of Reading includes four abilities that a reader needs: 1) coding competence, 2) semantic competence, 3) pragmatic competence, and 4) critical competence. As a code breaker (coding competence) a reader breaks the code of written texts by recognizing and using fundamental features in the text. As a meaning maker (semantic competence) a reader takes into account each text's interior meaning systems in the comprehension process. When acting as a text user (pragmatic competence) a reader uses texts functionally by taking into account the different cultural and social functions that various texts perform. As a text critic (critical competence) a reader analyses texts critically keeping in mind that texts are not ideologically neutral but represent particular points of view.

Because becoming literate is such a complicated process, young learners need support when aiming to fulfil various challenging expectations. It is important to give children opportunities to make choices about their literacy learning. When they are allowed to read material that is relevant to their lives, they become engaged and proficient readers who enjoy reading. (Sanacore, 2012.) For young children, kindergarten is the learning environment that supports their emerging literacy skills. If there are available in several places, reading and writing materials, children can use them any time they want independently. Possibilities for literacy activities enhance the development of children's skills especially activities that include interaction between adults and children during reading, group work and play. (Ball \& Gettinger, 2009.)

Teachers' knowledge of language and literacy development is essential in creating high-quality interactions. Children's literacy development requires a strong physical and psychological literacy environment. The role of preschool teachers is central in ensuring that literacy-enriched environments succeed in promoting children's literacy development. (Guo, Justice, Kaderavek \& McGinty, 2012.) It is also important to keep in mind, that what kind of picture a child constructs of himself or herself as a learner is largely based on the feedback he or she gets from the teacher. If learning is easy and the child gets experiences of success and positive feedback, his or her confidence in himself or herself as a learner strengthens. (Cunningham \& Cunningham, 2002.)

Fluent reading is more than fast reading. It includes accuracy, automatic word identification, decoding with facility, and expressiveness in reading. These support the reader's comprehension of the text. On one hand fluent reading makes comprehension of the text easier and on the other hand comprehension supports aspects of fluency such as pacing. Consequently, a fluent reader reads with ease of word recognition, appropriate pacing, phrasing, and intonation. A non-fluent reader has difficulties in understanding a text. Rapid word identification and the construction and integration of meaning are essential in the reading process, but for a non-fluent reader word identification demands mental capacity 
that would be needed for the comprehension process. (Hurry \& Doctor, 2007; Kuhn, Schwanenflugel \& Meisinger, 2010; Schellings, Aarnoutse \& van Leeuwe, 2006.)

\section{Reading Comprehension}

Understanding the meaning of a text is the primary purpose of reading. However, reading comprehension is a complex process. The reader constructs meaning by interacting with text using his or her previous knowledge and experience and the information that can be found in the text. Reading is thinking cued by written language. A skilful reader finds several pieces of information in the text that make the understanding easier. The text is an intermediary between reader and text. When creating the text the writer has used certain words, phrases, syntax, and style. The reader utilizes these elements when constructing meaning for the text. In addition, the reader uses elements from other texts he or she has read recently. This means that the texts he or she reads affect his or her development as a reader. (Blair-Larsen \& Vallance, 2004; Goodman, 1996; Pardo, 2004; Scharer, Pinnell, Lyons, \& Fountas, 2005.)

It is important that children learn already during their early school years to read and critically evaluate information from different sources. They should be given frequent opportunities to read also informational texts and acquire skills that they need at school when reading subject area textbooks. (Brozo, 2010.) They should learn to use appropriate comprehension strategies in different reading situations, such as previewing, activating prior knowledge, predicting, making connections, monitoring, organising, summarising, questioning, and visualising. These strategies are necessary because they can supply access to knowledge that is beyond young readers' personal experience. A skilful reader is able to decide which strategies to use depending on the content of the text and its level of difficulty. (Barton \& Sawyer, 2003; Bimmel \& van Shooten, 2004; Dougherty Stahl, 2004; McLaughlin, 2006.)

Interest in the content of the text has an effect on reading comprehension. It seems that boys are more affected by the interest level of the reading material than girls. If a boy is interested in the content of a text he wants to understand what he is reading. This in turn will stimulate processes that are important in comprehension, for instance, making inferences based on text and reader's previous knowledge. Nevertheless, girls understand both fiction and non-fiction better than boys, and the difference between the two genders' skills becomes even more significant in higher grades. One explanation may be that many boys lack ability to read texts effectively; they do not read texts from the beginning to the end but dip in and out. Because there will be several occasions when boys have to read and understand texts that they do not find interesting, it is necessary to teach them adequate reading strategies. (Oakhill \& Petrides, 2007; Prado \& Plourde, 2011; Topping, Samuels, \& Paul, 2008.)

\section{Reading Attitudes}

If a child has developed a positive attitude towards reading already before entering school it will, through its influence on his or her engagement and practice, have a positive effect on the future development of his or her literacy skills (LaCour, McDonald, Tissington \& Thomason, 2013; McKenna, Kear, \& Ellsworth, 1995). Accordingly, several studies have shown that reading engagement or the time students spend reading for pleasure correlate significantly with their reading achievement. A child who values reading wants to explore various literacy situations, and has reasons to use reading in a meaningful way. (Brozo, Shiel, \& Topping, 2008; Wigfield \& Barbosa, 2008.) As was mentioned above, boys' reading skills are not as good as girls' skills and girls succeed better than boys in every area of literacy. The differences in their literacy skills are mainly due to their different attitudes towards reading. These in turn, are a result of gender differences in values, goals and out-of-school activities. To decrease the gender gap, new ideas that seek to attract interest and engagement among boys in literary culture and that help them to find pleasure in reading, are badly needed. (Välijärvi et al., 2007.)

Researchers have examined issues of students' motivation for reading and reading achievement from different perspectives. Lynn and Mikk (2009) found differences in boys' and girls' activities at school and at home. Girls spend more time reading and boys using computers and DVD players. Chiu and McBride-Chang (2006) looked at gender differences in reading achievement and reading enjoyment using the PISA data set and they found that enjoyment mediated $42 \%$ of the gender difference in achievement.

In order for any type of reading instruction to be effective, students need to be attentive and engaged when learning. Although they are taught in the same way, boys and girls may spend different amounts of time engaged in literacy activities. This is a result of the differences in concentration, interest and preference for different types of activities. Consequently, it is important to explore what types of learning environments are motivating especially to boys 
and what kind of reading instruction is effective in focusing their attention. During the school years, students' investments in schoolwork decline. For some students - especially male students - this may be a result of lagging behind in school. Various studies have shown that the relations between developments in investment and achievement are somewhat stronger for boys than for girls. (Honstra, van der Veen, Peetsma, \& Volman, 2013; Logan \& Johnston, 2010.)

When aiming to break through the decline of reading motivation when children grow older, one should focus on enhancing autonomous reasons for reading, which means that children read because they enjoy it. However, one has to keep in mind that different motives for reading may be central when children are reading in their leisure-time or at school. Even if they lack spontaneous interest in reading but consider reading relevant or important they can be motivated to engage in reading activities. When teachers' goal is to create a positive reading climate among their students, they should give them opportunities to make choices, offer good reasons for doing things, recognize students' interests, and give them support and help when they need it. This helps to break through the declining trend in reading motivation throughout children's educational career. (De Naeghel, Van Keer, Vansteenkiste, \& Rosseel, 2012.)

\section{Methodology}

The goal of the study was to examine what kind of self-esteem, reading skills, and reading attitudes the first and the second graders have and if boys and girls differ in these aspects. In addition, it aimed to find out if there is interdependence between students' self-esteem, skills, and attitudes. In this article, the focus is in students' reading skills and reading attitudes. The results of the self-esteem measurement are presented in the manuscript by Soininen \& Merisuo-Storm. When the reading measurements were conducted the first graders had been studying reading only for a couple of weeks. Therefore, only the second graders' reading skills could be assessed with a reading comprehension test. However, all the students took part in the reading attitude measurement.

Altogether 291 children (141 boys and 150 girls) took part in the reading comprehension test. At that time, they had studied in the second grade from two to five weeks and they were 7-8 years old. They read a nonfiction text of a squirrel and answered questions related to the text. Answers to the easiest questions could be found in the text but when answering the most difficult questions (questions $3 \&$ 4) the students had to make connections that are not clearly expressed in the text. It means that they had to be able to "read between the lines". The students answered three questions by writing and one question (question 2) by ticking the right alternatives from a list. In addition, there were three words picked from the text (question 5) and the students were asked to choose a synonym for each of these words from three alternatives. (Figure 1.)

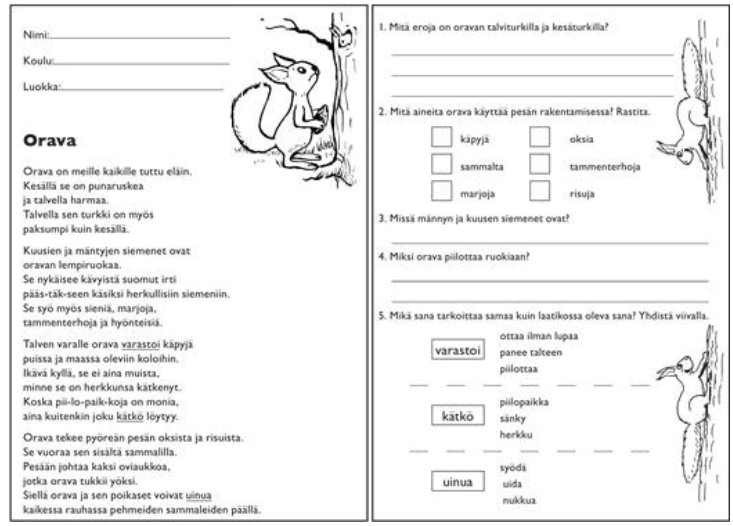

Figure 1. Reading comprehension test

To find out what kind of reading attitudes the first and second graders have towards reading we constructed a questionnaire including 17 questions for all pupils and five extra questions for the second graders. The questionnaire covers four different areas: 1) attitudes towards reading, 2) attitudes towards studying, 3) attitudes towards social reading, and 4) feeling of competence. The scale used in the questionnaire is a Likert-type 1-4 (agree-disagree). Both instruments have a very good internal consistency with Cronbach's alpha of 0.90 in the first-grade-version and 0.89 in the 
second-grade-version.

Also this measurement was done during the first weeks of the school year and 563 children (281 boys and 259 girls) took part in it. About half of the pupils studied in the first grade $(n=267 ; 136$ boys and 131 girls) and the other half in the second grade $(n=296 ; 145$ boys and 151 girls). At that time the students were 7-8 years old. When filling the questionnaire the students gave their opinions of several issues related to reading and literacy learning.

The questions were worded in such a manner as to be unambiguous and easy to understand. When answering a question the student ticked the one of the four teddy bears placed above the question that best illustrated his or her opinion about the asked matter. The expressions on the bear's faces are easy to understand (Figure 2). The very happy teddy bear means that the student loves to do what he or she is asked about or considers it very easy, the smiling teddy bear means he or she does it with pleasure or considers it easy, the tired and unhappy teddy bear means he or she would not want to do it or considers it difficult, and the repulsed teddy bear means he or she would hate to do it or considers it very difficult. The very happy teddy bear is assigned a score of three. The repulsed teddy bear receives a score of zero. In order to confirm that all students had understood what they were expected to do, the researcher and the class had talked about how the teddy bear felt in each picture. Moreover, the children answered, supervised by the researcher, one extra question before they started filling the questionnaire.

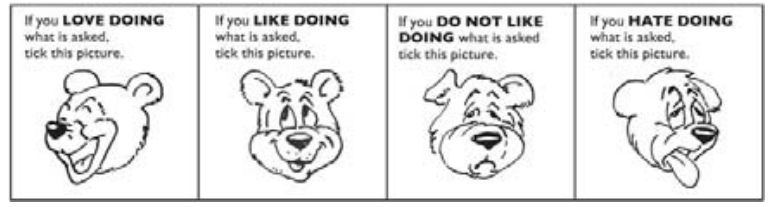

Figure 2. Four answer alternatives and the pictures related to them

The first seven questions are the same in the first and the second grade questionnaires. The purpose of these questions was to find out what kind of opinions the students have towards reading. The second section includes five questions. They are in both questionnaires related to same themes although there are slight differences in wording. For instance, in the first grade questionnaire is asked 'Do you like to learn to read?' and in the second grade questionnaire 'Did you like to learn to read?'. In the third and the fourth part of the questionnaire the second graders have more questions than the first graders. Opinions about social reading are examined with three questions in the first grade and with five questions in the second grade. The number of the questions related to student's feeling of reading competence is three in the first grade questionnaire and five in the second grade questionnaire. As there are 17 questions in the first grade questionnaire the maximum score for the first graders is 51 . In the second grade questionnaire the number of questions is 22 and maximum score is 66.

\section{Results}

\subsection{Reading comprehension}

As was mentioned above, the second graders read a non-fiction text of a squirrel. After that, they answered questions related to the text. The easiest to answer were the two questions that children answered by choosing right alternatives from a list. More than half of the students (66\%) were able to find right synonyms to all the three words picked from the text. Equally many students (65\%) found all the three materials that the squirrels use when building their nests. However, $15 \%$ of the boys and $9 \%$ of the girls had chosen at least two incorrect alternatives. The question, "What are the differences in squirrel's summer fur and winter fur?" indicates that there are more than one difference. Still, less than a third of the students (30\%) had mentioned both differences: colour and thickness.

To be able to answer the most difficult questions the students needed to make connections that are not clearly expressed in the text. They were asked: "Where are the seeds of a pine and fir tree?" and "Why does the squirrel hide its food?". Nevertheless, $15 \%$ of the girls and $11 \%$ of the boys answered the question about the seeds correctly and $27 \%$ of the girls and $19 \%$ of the boys the question about the food correctly. This shows that several children have already after one school year very good reading comprehension skills. Therefore, it is important that the teacher gives them reading material and exercises that are difficult enough. This ensures that also their skills develop during the literacy lessons. 
These skilled readers were more often girls than boys $(t=-2.25, p=.025)$. Although the boys had answered other questions almost as well as the girls, the girls aggregated scores of the reading comprehension test are significantly better than the boys scores $(t=.275, p=.006)$.

\subsection{Reading attitudes}

The results of the reading attitude measurement show that in the first and the second grade students' opinions about reading and reading related activities were in average positive. However, in the first grade the boys' opinions were significantly more negative than the girls' $(\mathrm{t}=-4.81, \mathrm{p}=.000)$ but in the second grade the difference was not significant. While in the first grade questionnaire the maximum aggregated score is 51, the mean value of the boys' scores is 35.0 (SD 11.1) and the mean value of the girls' scores 40.7 (SD 8.2). More than half of the girls (56\%) and more than one third of the boys (39\%) had very positive attitudes (51-40 scores). Only five boys (4\%) and one girl (1\%) had very negative attitudes ( $0-10$ scores). In the second grade questionnaire the maximum aggregated score is 66 . The mean value of the boys' scores is 47.4 (SD 11.4) and of the girls' scores 50.1 (SD 9.6). One quarter of the boys (24\%) and more than one third of the girls (38\%) had very positive attitudes towards reading (66-55 scores). Only three boys (2\%) and one girl (1\%) had very negative attitudes (15-20 scores).

Almost half of the students loved reading in general. In the second grade an eager reader proved to be as often a boy (48\%) as a girl (49\%). Nevertheless, in the first grade only $38 \%$ of the boys but $59 \%$ of the girls had equally positive opinions about reading. The goal of the first part of the questionnaire was to clarify what reading materials and reading related activities children like most. Both girls and boys gave most positive answers when they were asked about visiting a library. Almost all students (96\%) had ticked one of the two most positive alternatives. The answers showed also that in both grades the girls' opinions about getting a book as a present $(t=-4.85, p=.000 ; t=-3.85, p=.000)$ and reading fairytales ( $t=4.71, p=.000 ; t=5.47, p=.000$ ) were significantly more positive than the boys' opinions. In the first grade $13 \%$ and in the second grade $6 \%$ of the boys stated that they hate getting a book as a present. Nevertheless, the boys enjoyed reading comics and non-fiction books.

The purpose of the second part of the questionnaire was to find out what kind of attitudes the first and the second graders had towards studying. They proved to be slightly less positive than the attitudes towards reading. Furthermore, it seems that in the beginning of the first grade the girls had significantly more positive attitudes towards studying than the boys $(t=-4.24, p=.000)$ but in the second grade the difference between the two genders was not significant. However, there were still boys and girls who did not like studying. In the second grade the aggregated scores of this section vary between $0-15$ and $11 \%$ of the students had very negative attitudes ( $0-4$ scores).

The first graders liked doing exercises in literacy lessons more often than the second graders. In the first grade, $39 \%$ of the boys and $57 \%$ of the girls loved doing them. However, already in the autumn of the first school year one quarter of the boys (24\%) and $8 \%$ of the girls hated them. In the second grade, only $33 \%$ of the boys and $37 \%$ of the girls loved doing them and $33 \%$ of the boys and $18 \%$ of the girls hated them. The difference between the two genders was significant in both grades ( $t=-4.12, p=.000 ; t=-2.73, p=.007)$. In both grades the students liked homework even less and the boys disliked doing them significantly more often than the girls ( $t=-4.33, p=.000 ; t=-2.34, p=.000$ ). In the first grade $25 \%$ of the boys and $7 \%$ of the girls and in the second grade $20 \%$ of the boys and $11 \%$ of the girls hated them. However, more than a third of students (39\%; 34\%) in both grades loved doing them.

Students' attitudes towards social reading were measured for instance with questions "Do you like to talk about books with other students?", "Do you like to tell about a book you have read to other students?". "Do you like to do exercises in literacy lessons with another student?", and "Do you like to read aloud in class?". In both grades, the girls had significantly more positive attitudes towards social reading than the boys $(t=-3.94, p=.000 ; t=-3.06, p=.002)$. They were for instance, significantly more often willing to do exercises with another student $(t=-4.12, p=.000 ; t=-3.18, p=$ .002). Only one quarter of the boys ( $25 \%$ ) and about one third of the girls (38 \%) loved to read aloud in class. Many children ( $23 \%$ of the boys and $12 \%$ of the girls) found it frightening and they said that they hate it. Many other studies have same kind of results (e.g. Merisuo-Storm 2006; Eriksson 2002; Gambrell 1996). Those children who most enjoyd telling about a book (34\% of the students) were most often the same who loved to talk about books with other students. There is a strong correlation between the answers to these two questions $(r=.585, p=.000)$.

The purpose of the last part of the questionnaire was to find out how strong feeling of reading competence the students have. They were asked how easy it is (or was) to learn to read and how easy it is to read, understand and remember texts they read. In the first grade in the middle of the learning process there is very little difference in the girls' and the boys' opinions. Almost half of them ( $45 \%$ of the boys and $49 \%$ of the girls) find learning to read very easy. 
However, it is not easy for all students and $17 \%$ of the boys and $4 \%$ of the girls said that it is very difficult. In the second grade $42 \%$ of the boys and $37 \%$ of the girls remembered that learning was very easy and only $4 \%$ of the boys and $3 \%$ of the girls remembered that they had great difficulties in learning.

In the second grade the boys assessed their reading skills higher than the girls. Most of the students $(81 \%$ of the boys and $75 \%$ of the girls) stated that reading is very easy. Only $6 \%$ of the boys and $2 \%$ of the girls found it difficult of very difficult. In addition, about half of the students had found that understanding the texts they read at school was very easy (54\% of the boys and $49 \%$ of the girls). Only $13 \%$ of the boys and the girls found understanding difficult or very difficult. More than half of the boys (63\%) and about half of the girls (49\%) considered understanding the meaning of the words in a text very easy. Only $2 \%$ of the students found it very difficult. The students felt that most difficult was to remember the contents of a text they had read. Only about one third of the students (35\% of the boys and $31 \%$ of the girls) thought that it was very easy. About one quarter of them (24\% of the boys and $23 \%$ of the girls) found it difficult or very difficult. There is a strong correlation between the students' assessment of their ability to understand the texts they read and to remember the contents of those texts $(r=.389, p=.000)$.

It is interesting to compare students' opinions of their reading skills with the results of the reading comprehension test. It is obvious that the boys had high confidence in their own reading skills. However, the reading test shows that they had assessed their skills better than they actually were. The girls had assessed their skills much more realistically. It is also interesting that although the boys valued reading and reading related activities less than the girls their feeling of reading competence was higher than the girls'.

\subsection{Interdependence between reading attitudes, reading skills, and self-esteem}

There is a strong correlation between all parts of the reading attitude questionnaire. The students who had a positive attitude towards reading enjoyed also studying $(r=.594, p=.000)$ and social reading $(r=.605, p=.000)$. Similarly, the students who had a positive attitude towards studying liked to do reading related activities with other students $(r=.723$, $p=.000$ ). Especially for the boys, the feeling of reading competence was significantly related to their attitudes towards studying ( $r=.413, p=.000)$. Those boys who had high confidence in their skills enjoyed schoolwork.

Equally, in the second grade there was a strong correlation between students' self-esteem, reading attitudes, and reading comprehension skills. The students who had a good self-esteem had a positive attitude towards reading $(r=.419$, $p=.000)$ and good reading comprehension skills $(r=.320, p=.000)$. These students were also happy to do reading related activities with other students $(r=.340, p=.000)$. It seems that for the boys good self-esteem is even more closely related to their attitudes towards studying $(r=.453, p=.000)$ than for the girls $(r=.323, p=.001)$.

According to Borba $(1989 ; 1994)$ and Reasoner $(2010)$ strong, healthy self-esteem is built on five building blocks: security, selfhood, affiliation, mission, and competence. All of them correlated strongly with students' reading skills and attitudes. This was the case especially for the boys. For the boys their feeling of security had stronger relations with their attitudes towards studying $(r=.270, p=.000)$ than for the girls $(r=.167, p=.076)$. Also the other building blocks of selfesteem are more closely linked in the boys' than in the girls' results. For instance, selfhood and attitudes towards studying (boys: $r=.462, p=.000$; girls: $r=.291, p=.002$ ), selfhood and social reading (boys: $r=.462, p=.000$; girls: $r=$ $.302, p=001$ ), affiliation and attitudes towards studying (boys: $r=.423, p=.000$; girls: $r=.286, p=.005$ ), and mission and attitudes towards studying (boys: $r=.347, p=.000 ;$ girls: $r=.286, p=.003$ ).

\section{Conclusion}

The first school years are an important phase of a child's life. The children's experience of this phase has a far-reaching effect on their attitudes towards school and it shapes their view of themselves as learners for years to come. The teacher has an important role when a child assesses himself or herself as a student. If a child gets positive experiences and feedback when studying he or she becomes more confident as a student. The school should be an environment where every child gets support he or she needs from adults. Children are willing to do also demanding tasks if they work in an environment, which supports each student individually. Motivation and achievement beliefs are important especially when tasks become more challenging. Also the motivation of those students whose skills are well developed may decrease if they have to do exercises that are too easy for them. (Georgiou, Manolitsis, Nurmi \& Parrila 2010, 7-8; Pakarinen, Kiuru, Lerkkanen, Poikkeus, Siekkinen \& Nurmi 2010, 295.)

When filling the reading attitude questionnaire the students gave the most negative answers when they were asked to give their opinions about homework and exercises during literacy lessons. The boys had even more negative 
opinions than the girls. It would be important to consider what kind of tasks would interest the students - especially boys. The students should also get individual tasks that are interesting and of proper level of difficulty. In addition, a student should not be doing same kind of tasks day after day. A large variety of different tasks motivates and also develops students' skills broadly. Especially boys do not want to do tasks that they do not consider meaningful. Teachers could plan exercises and homework together with students. They might want to read for instance articles in sport magazines, manuals of some device, TV-guides, or stories in comic books and do exercises related to them with pleasure. Interesting tasks develop students' reading skills and positive attitudes much more effectively than the tasks that they find unattractive.

The results of the study show that students' self-esteem has a strong effect on their learning and attitudes. This is the case especially for the boys. However, when we know how important it is for the first and the second graders to acquire good reading skills, it is also possible that learning to read has a positive effect on young students' self-esteem. Therefore, it is essential that the teachers support the positive development of each student's self-esteem as well as reading skills and attitudes. Children, who are confident and happy being what they are as well as get well along with their peers, enjoy studying. Even more often than those children who are conscientious or have a high feeling of competence.

\section{Reference}

Ball, C. \& Gettinger, M. (2009). Monitoring children's growth in early literacy skills: Effects of feedback on performance and classroom environments. Education and Treatment of Children, 32(2), 189-212.

Barton, J. \& Sawyer, D. M. (2003). Our students are ready for this: Comprehension instruction in the elementary school. The Reading Teacher, 57(4), 334-347.

Bimmel, P. \& van Schooten, E. (2004). The relationship between strategic reading activities and reading comprehension. L1 Educational Studies in Language and Literature, 4(1), 85-102.

Blair-Larsen, S. M., \& Vallance, K. M. (2004). Comprehension instruction in a balanced reading classroom. In S. M. Blair-Larsen \& K. A. Williams (Eds.) The Balanced Reading Program: Helping All Students Achieve Success (pp. 37-52). Newark, DE: International Reading Association.

Borba, M. (1989). Esteem Builders. A K - 8 Self- Esteem Curriculum for Improving Student Achievement, Behavior and School Climate. Torrance, CA: Jalmar Press.

Borba, M. (1994). Home Esteem Builders. Torrance, CA: Jalmar Press.

Brozo, W. G. (2010). The role of content literacy in an effective RTI program. The Reading Teacher, 64(2), 147-150.

Brozo, W. G., Shiel, G., \& Topping, K. (2008). Engagement in reading: Lessons learned from three PISA countries. Journal of Adolescent \& Adult Literacy, 51(4), 304-315.

Chiu, M. M., \& McBride-Chang, C. (2006). Gender, context, and reading: A comparison of students in 43 countries. Scientific Studies of Reading. 10, 331-362.

Cunningham, P. M. \& Cunningham, J. W. (2002). What we know about how to teach phonics. In A. E. Farstrup \& S. J. Samuels (Eds.), What research has to say about reading instruction (pp. 87-109). Newark, N.J.: International Reading Association.

Dougherty Stahl, K. A. (2004). Proof, practice, and promise: Comprehension strategy instruction in the primary grades. The Reading Teacher, 57 (7), 598-609.

Goodman, K. S. (1996). On Reading. Portsmouth, NH: Heinemann.

Guo, Y., Justice, L. M., Kaderavek, J. N., \& McGinty, A. (2012). The literacy environment of preschool classrooms: contributions to children's emergent literacy growth. Journal of Research in Reading, 3 (3), 308-327.

Hornstra, L., van der Veen, I., Peetsma, T., \& Volman, M. (2013). Developments in motivation and achievement during primary school: A longitudinal study on group-specific differences. Learning and Individual Differences 23(1), 195-204.

Hurry, J. \& Doctor, E. (2007). Assessing literacy in children and adolescents. Child and Adolescent Mental Health, 12(1), 38-45.

Kupari, J., Sulkunen, S., Vettenranta, J., \& Nissinen, K. (2012). Enemmän iloa oppimiseen. Neljännen luokan oppilaiden lukutaito sekä matematiikan ja luonnontieteiden osaaminen. Kansainväliset PIRLS- ja TIMSS-tutkimukset Suomessa. University of Jyväskylä, Finnish Institute for Educational Research.

LaCour, M. M., McDonald, C., Tissington, L. D., \& Thomason, G. (2013). Improving pre-kindergarten children's attitude and interest in reading through a parent workshop on the use of dialogic reading techniques. Reading Improvement, 50(1), 1-11.

Logan, S. \& Johnston, R. (2010). Investigating gender differences in reading. Educational Review 62(2), 175-187.

Luke, A. \& Freebody, P. (1999). Further notes on the four resources model. Derived from www.readingonline.org/research /lukefreebody.html.

Lynn, R. \& Mikk, J. (2009). Sex differences in reading achievement. TRAMES: A Journal of the Humanities \& Social Sciences, 13(1), 313.

McKenna, M. C., Kear, D. J., \& Ellsworth, R. A. (1995). Children's attitudes toward

reading: A national survey. Reading Research Quarterly, 30, 934-956.

McLaughlin, M. (2006). Guided comprehension in the primary grades. Newark, DE: International Reading Association. 
Mullis, I. V. S., Martin, M. O., Kennedy, A. M., Trong, K. L., \& Sainsbury, M. (2009). PIRLS 2011 Assessment Framework. Amsterdam: International Association for the Evaluation of Educational Achievement (IEA).

De Naeghel, J., Van Keer, H., Vansteenkiste, M., \& Rosseel, Y. (2012). The relation between elementary students' recreational and academic reading motivation, reading frequency, engagement, and comprehension: A self-determination theory perspective. Journal of Educational Psychology 104(4), 1006-1021.

Oakhill, J. V. \& Petrides, A. (2007). Sex differences in the effects of interest on boys' and girls' reading comprehension. British Journal of Psychology, 98(2), 223-235.

OECD. (2013). PISA 2012 Results in Focus. What 15-year-olds know and what they can do with what they know. Paris: OECD.

Pardo, L. S. (2004). What every teacher needs to know about comprehension. The Reading Teacher, 58(3), 272-280.

Prado, L. \& Plourde, L. A. (2011). Increasing reading comprehension through the explicit teaching of reading strategies: Is there a difference among the genders? Reading Improvement, 48(1), 32-43.

Reasoner, R. W. (2010). The true meaning of self-esteem. Fulton, MD: National Association for Self-esteem. Retrieved from Http://www.self-esteem-nase.org/whatisselfesteem.shtml.

Sanacore, J. (2012). Showing children that we care about their literacy learning. Preventing School Failure, 56(3), 188-195.

Scharer, P. L., Pinnell, G. S., Lyons, C., \& Fountas, I. (2005). Becoming an engaged reader. Educational Leadership, 63(2), 24-26.

Schellings, G., Aarnoutse, C. \& van Leeuwe, J. (2006). Third-grader's think-aloud protocols: Types of reading activities in reading an expository text. Learning and Instruction, 16, 549-568.

Suggate, S. P., Schaughency, E. A., \& Reese, E. (2013). Children learning to read later catch up to children reading earlier. Early Childhood Research Quarterly, 28, 33-48.

The final report of EU high-level group of experts on literacy. (2012). Retrieved from http://ec.europa.eu/education/literacy/what-eu/highlevel-group/documents/literacy-report.pdf.

Topping, K. J., Samuels, J., \& Paul, T. (2008). Independent reading: the relationship of challenge, non-fiction and gender to achievement. British Educational Research Journal, 34(4), 505-524.

Välijärvi, J., Kupari, P., Linnakylä, P., Reinikainen, P., Sulkunen, S., Törnroos, J., \& Arffman, I. (2007). The Finnish success in PISA and some reasons behind it 2. University of Jyväskylä.

Wigfield, A., Guthrie, J. T., Perencevich, K. C., Taboada, A., Klauda, S. L., McRae, A, \& Barbosa, P. (2008). Role of reading engagement in mediating effects of reading comprehension instruction on reading outcomes. Psychology in the Schools, 45(5), 432-445. 